\title{
Female fatality due to cholera was higher than male. Studies of four cholera epidemics in the Poznań Province in the second half of the 19th century
}

Grazyna Liczbinska ( $\square$ grazyna@amu.edu.pl )

Adam Mickiewicz University in Poznań

Miroslav Králík

Masaryk University

\section{Research Article}

Keywords: Morbidity and Mortality, Death Registers, Division of Social Roles, Contaminated Water

Posted Date: March 19th, 2021

DOI: https://doi.org/10.21203/rs.3.rs-288643/v2

License: (c) (i) This work is licensed under a Creative Commons Attribution 4.0 International License.

Read Full License 
Female fatality due to cholera was higher than male. Studies of four cholera epidemics in the Poznań Province in the second half of the $19^{\text {th }}$ century.

Grażyna Liczbińska ${ }^{1}$, Miroslav Králík ${ }^{2}$

${ }^{1}$ Institute of Human Biology and Evolution, Faculty of Biology, Adam Mickiewicz University, Poznań, Uniwersytetu Poznańskiego 6, 61-614 Poznań, Poland grazyna@amu.edu.pl

${ }^{2}$ Department of Anthropology, Faculty of Science, Masaryk University, Kotlářská 267/2

61137 Brno, Czech Republic

18313@muni.cz

Correspondence:

Grażyna Liczbińska, grazyna@amu.edu.pl 


\begin{abstract}
Males and females differ in terms of patterns of morbidity and mortality resulting from diseases. It has been tested whether cholera epidemics killed selectively by sex in historical populations. Four cholera epidemics in the Poznań Province: 1852, 1855, 1866, and 1873 have been studied. Data have been derived from death registers of the selected parishes located on the territory of the Poznan Province. In total, the information about 34, 655 individual cases, with the causes of deaths recognized, has been used, encompassing 18,243 males and 16,325 females. More females than males died in the periods of cholera epidemics than in non- epidemic ones. The values of sex ratio at death from cholera (SRDCh) during the earlier epidemics $(1852,1855)$ and later epidemics $(1866,1873)$ were 0.91 and 0.97 , respectively. A significant variances in the sex ratio at death (SRD) have been observed between the cholera epidemics periods $(\mathrm{SRD}=0.89)$ and non-epidemic periods $(\mathrm{SRD}=1.13)$ in Poznan. The gender-specific cholera death rates could have been related to the division of social roles between women and men. Women more frequently than men had contact with contaminated water, e.g. when preparing and cooking meals, feeding, caring for and washing children and caring for sick family members.
\end{abstract}

\title{
List of abbreviations
}

SRD - the sex ratio at death

$\mathrm{SRDCh}-$ the sex ratio at death from cholera 


\section{Introduction}

It is widely recognized that males and females have different patterns of illness ${ }^{1-2}$. Preston $^{3}$ for example found a consistent excess of mortality due to tuberculosis in women aged 5-29, and further research confirmed that deaths due to tuberculosis predominated among adolescent girls and young women in comparison to boys and young men ${ }^{4-5}$. Among children diphtheria was frequently mentioned as a disease which had higher mortality rates in boys, while whooping cough was consistently referred to as causing higher mortality in girls. Poliomyelitis, malaria, and typhoid were diseases which showed consistently higher male mortality in childhood ${ }^{4-5}$. Deaths due to measles prevailed in females and this pattern has been repeated in all the major regions of the world: Europe, North and South America, Far-East Asia, the Middle East and South Asia ${ }^{6}$. According to Singh and a team ${ }^{7}$, girls have higher measles fatality rates due to lack of immunization, but there is no sex specificity regarding antibody response ${ }^{8}$. Women are also more susceptible to a variety of autoimmune diseases including systemic lupus erythematosus, multiple sclerosis, primary biliary cirrhosis, rheumatoid arthritis and Hashimoto's thyroiditis 9 . Moreover, higher mortality due to such diseases as: typhoid fever, anthrax, meningococcal infection, tetanus, hepatitis $\mathrm{C}$ was noted in men in all age classes, while in women aged 1-49 deaths due to smallpox, rubella, pertussis, streptococcal infection (scarlet fever, erysipelas) prevailed. Moreover, in young adult women such diseases as: paratyphoid fever, syphilis, hepatitis B, influenza and leprosy was frequently observed ${ }^{10}$. The results for sex selectivity of the plague are ambiguous. The $17^{\text {th }}$ and $18^{\text {th }}-$ century plagues killed women more often than men ${ }^{11-14}$, which was supported by Curtis and Roosen ${ }^{15}$ in their research on Black Death in the Netherlands, from the $14^{\text {th }}$ to $16^{\text {th }}$ centuries. Meanwhile studies of plague epidemics in London in 1592-1593, 1603 and 1625 give reverse results: male deaths outnumbered female ones ${ }^{16}$. In turn, other authors claim, that the plague does not clearly select either $\operatorname{sex}^{17}$. 
The question arises about the reason of sex-selective mortality due to diseases. According to Johansson ${ }^{18}$ young males are less capable (less buffered) than females of effectively responding to environmental insults. Females generate a more robust immune response than males after a clash with an infectious agent, and they respond to natural and vaccine exposures by producing substantially more antibodies ${ }^{19}$. Genetic explanations are focused on possession of two X chromosomes by females, i.e., which gives more variable genetic background for immune system in females than in males, and this in turn results in their stronger immune responses ${ }^{20-21}$. Having two different alleles on the two X-chromosomes may also contribute to the physiological diversity, which can be advantageous when encountering new immune challenges ${ }^{22}$. Muenchhoff and Goulder ${ }^{23}$ showed that females are less susceptible to infections than males due to their stronger Th1 immune responses. High level of testosterone may cause immuno-suppression and increase morbidity and mortality ${ }^{24-}$ ${ }^{25}$. Men tend to be more susceptible to a variety of diseases: both the incidence of infections and their intensity are often higher in men than in women ${ }^{26}$. The research of Zarulli and the team $^{22}$ shows that in crises caused by epidemics and famines women at all ages survived longer than men did.

Wizemann and Pardue ${ }^{26}$ claim, that "most sex differences in humans, however, are caused by differences in exposures (a societal level effect) instead of differences between males and females at the individual, organ, or cell level" (p.116). Nevertheless, the attention is given to behavioural differences, related to the fact that women care more about themselves (in terms of health) than men. Differences are also observed in smoking, drinking and dietary patterns to the disadvantage of $m^{27}{ }^{27}$ in the frequency of girls and boys attending schools ${ }^{28-}$ ${ }^{29}$, and/ or in frequency, nature and intensity of male and female contacts with infectious agents and in exposure to them due to household daily activities ${ }^{30}$. 
This article will examine whether cholera epidemics killed selectively by sex in historical populations. This goal will be achieved by using data from four cholera epidemics, which occurred in the Poznań Province in 1852, 1855, 1866 and 1873.

\section{Results}

The weekly distribution of deaths during subsequent cholera epidemics is shown in Figs. 3a-3d. In 1852 the cholera epidemic started in mid-July (first deaths recorded) and lasted until the end of October (last deaths recorded), with the highest number of deaths - up to 25 deaths per day observed during its strongest course, i.e. from mid-August to the beginning of September. At that time, from 70 to 120 deaths per week were noted (Fig. 3a). Another cholera epidemic lasted from mid-August 1855 to the end of October 1855.

Compared to the epidemic that had occurred three years earlier, it lasted shorter and its impact was weaker than earlier, which was reflected by a lower number of deaths than in 1852, i.e. 1-2 people died per day, while in the period of its greatest intensity - up to 4 people died per

day, and up to 12 deaths per week were noted (Fig. 3b). The cholera epidemic in 1866, lasting from 24 June till the end of October, was responsible for over 12 deaths per day and over 45 per week in its strongest course (Fig. 3c). The last outbreak of cholera was recorded from the end of July 1873 to the end of September 1873 (the last single death was recorded in November). Its course was shorter and the effects were weaker compared to the epidemic in 1866: 4 individuals died per day and 10 individuals died per week at its peak (Fig. 3d).

The male-to-female death ratios by epidemiological weeks in 1852, 1855, 1866 and 1873 are shown in Figs. 4a-4d. In the greatest intensity of epidemic courses, female deaths outnumbered male ones.

Within the entire sample a significantly higher numbers of male deaths than female deaths were noted when an expected balance in the numbers of male and female deaths $=1: 1$ was assumed $($ Chi-squared $=19.90, \mathrm{df}=1, \mathrm{p}$-value $<0.0001)$. When the sex-specific death 
ratio of $\mathrm{M}: \mathrm{F}=0.50$ was assumed, the difference in the male-to-female death rate was also statistically significant $($ Chi-squared $=106.31, \mathrm{df}=1, \mathrm{p}$-value $<0.0001)$.

Fig. 5 (count-plots) and fig. 6 (smoothed - with densities) show the distribution of the deceased by their age at death outside the epidemic occurrences and within the epidemic occurrences. In the most sensitive age groups the patterns of deaths distribution by age were similar for non-epidemic occurrences and for cholera epidemic occurrences: more boys than girls died in infancy. In the group of elderly people more women died than men. What is striking however, are the excess death numbers of girls (teenagers and young women) and adult women in the periods when cholera epidemics occurred compared to non-epidemic periods.

Among all deceased in cholera epidemics, there were lower numbers of male deaths from cholera than female ones (unfortunately not significant; $p$-value $>0.05$ ), and differences in the rate of male-to-female deaths from cholera were statistically significant (Chi-squared $=$ $3.65, \mathrm{df}=1, \mathrm{p}$-value $<0.05)$. The frequency of male deaths during epidemic events was significantly lower than outside epidemic periods, while the frequency of female deaths in the cholera occurrences was significantly higher than in non- epidemic periods (Chi-squared $=$ 7.13, $\mathrm{df}=1, \mathrm{p}$-value $<0.01$ ). During earlier cholera epidemic courses, i.e. in 1852,1855 , and later cholera epidemics, in 1866 and 1873, the sex ratio at death due to cholera was below 1 , which means that more females than males died from cholera (SRDCh for earlier and later cholera epidemics: 0.91 and 0.97 , respectively).

Taking into account the size of the place of residence, the sex ratio at death in the city of Poznań was at the level of 1.13, while in towns and villages it was, 1.10 and 1.12, respectively $(p>0.05)$. The values of the sex ratio at death due to cholera were as follows: in Poznan 0.89 , while in towns and villages 1.43 and 1.26 , respectively $(\mathrm{p}>0.05)$. Evidently, only in Poznań the value was below 1; unfortunately, the difference was not significant (due to the 
small number of cases in towns and villages). However, in Poznań alone, a significant difference was observed in the sex ratio at death between the periods with cholera epidemics and the periods without cholera epidemics ( 0.89 and 1.13 , respectively) (Chi-squared $=10.28$, $\mathrm{df}=1$, p-value $<0.002$ ), which additionally confirms that more women died during cholera epidemics than men.

\section{Discussion}

Vibrio cholerae is the causative agent of cholera and is linked with the aquatic environment. More than 200 serotypes of Vibrio cholerae have already been identified and several of them can cause different symptoms: from mild symptoms, not requiring medical attention (observed in $80 \%$ of patients), to serious gastroenteritis, causing profuse diarrhoea, leading to dehydration and, in the most severe cases - to death (observed in 20\% cases) ) $^{31-32}$. The toxigenic strains of Vibrio cholerae serogroups $\mathrm{O} 1$ and $\mathrm{O} 139$ have been identified in cholera epidemics and pandemics ${ }^{33}$. In the past two centuries, cholera emerged and spread from the Delta of Ganges six times causing six pandemics: 1817-1823, 1826-1838, 18461863, 1865-1875, 1883-1896, and 1899-1923 ${ }^{34}$. The classical biotype was the etiological factor responsible for them. The seventh pandemic, lasting in 1961-1975, spread from Indonesia and the etiological factor was the biotype E1 Tor ${ }^{35-36}$. In the contemporary world cholera still remains a major cause of morbidity and mortality, particularly in lower-income countries with poor sanitary infrastructure and low hygiene ${ }^{37}$. The WHO estimates that the officially reported cholera cases represent only $5-10 \%$ of the actual number occurring annually worldwide. Of the estimated 3 to 5 million cases that occur globally every year, about 100,000 to 120,000 end in death ${ }^{38}$.

Our research indicates a higher risk of death from cholera among women than men. This is in line with observations coming from current cholera epidemics. The WHO report ${ }^{38}$ points to traditional social roles as a factor responsible for the surplus of deceased women and 
girls over men and boys. The higher incidences of cholera among women result from their potentially frequent contact with contaminated water when preparing and cooking meals, feeding, caring for and washing children, and caring for sick family members. A link between the increased morbidity and deaths from cholera and traditional division of roles, assigning women to run the household and to care for the sick, are confirmed by studies of cholera epidemics in northern Jakarta ${ }^{39}$ and in James Town, a community from the sub-Metropolitan area in Accra, Ghana ${ }^{40}$. A greater risk for symptomatic cholera in females than males was also confirmed by studies of cholera epidemics in Bangladesh ${ }^{41}$, in nomadic pastoralist groups from the sub-Saharan parts of Uganda ${ }^{42}$. Female cholera cases outnumbered male cases in Mpumalanga Province, South Africa ${ }^{43}$, which also had their socio-cultural justification. Men migrated from the Province in search for work and education more often than women, hence women predominated the Province population ${ }^{43}$. The example of cholera epidemic in Sierra Leone in 2012 also attributes the high morbidity and mortality rates among women to their roles in traditional society, i.e. running of the household and the care for children and the sick. The prevalence of women as rural traders travelling to markets in commercial centres also increased their vulnerability to contracting and transmitting the disease $\mathrm{e}^{44}$. Some gender differences were observed in eating practices: women in rural areas of Sierra Leone often practiced eating in groups, shared their food and ate with hands, while men used their own bowls and ate with spoons. Moreover, in the case of female traders, food was rather eaten raw than cooked ${ }^{44}$. Some African studies confirmed cholera cases more likely in males than in females. In fishing villages from Uganda men were at a higher risk of cholera due to frequent access to contaminated water than women ${ }^{45}$. This example reinforces the role of social factors responsible for the gender-specific cholera mortality.

Recently, attempts have been made to look for answers concerning sexual dimorphic differences in morbidity and mortality from cholera in biological reasons. Watanabe and a 
team $^{46}$ have reported that female mice are more sensitive to cholera toxin than male ones. According to the authors, the level of some proteins (ARH1 protein) may affect the gender specificity in the response to cholera toxins.

In our research the intensity of cholera epidemics, and hence the number of deaths, varied between urban and rural centres: cholera epidemics took the greatest toll in large cities, for example in the city of Poznań, while the smallest one in villages. The cholera epidemic in 1852 killed 1,724 people in Poznań, i.e. 3.9\% of the city population, 97 Poznań inhabitants died due to cholera in 1855 , and in 1866 the disease killed $2.4 \%$ of the city population ${ }^{47}$. There was also some variation in deaths numbers from cholera between Poznań districts. In a poor working-class district of Poznań, located on the right bank of the Warta River, deaths from cholera accounted for as many as $6 \%$ of all deaths ${ }^{48}$, while deaths in the group of $2-14$ years constituted of almost $9 \%$ of all deaths in this age category ${ }^{48}$. In the wealthier city centre deaths due to cholera epidemics in the 1850 s, 1866 and 1873 accounted for almost $5 \%$ of all deaths ${ }^{48}$. The outbreak of cholera epidemic in the wealthier Poznań city centre confirmed earlier assumptions that cholera had attacked only the poorest classes were wrong. In 1866 the epidemic was probably brought to Poznań in June to one of the taverns in the Old Market Square by raftsmen from Szczecin ${ }^{49}$.

The $19^{\text {th }}$-century Poznań was an overcrowded city, especially the downtown was suffocating within the walls of the fortifications. The city suffered from deficient infrastructure. Until the mid-1860s Poznan had no modern water supply system and for many inhabitants, the Warta River flowing through the city, was the source of drinking water ${ }^{50}$. The lack of the municipal sewage system contributed to poor conditions in the city (it was built as late as the end of the $19^{\text {th }}$ century) ${ }^{50}$. Thus, in small towns the cholera death rate was lower than in cities. For example, the town of Leszno owed the absence of epidemics of infectious diseases to its high sanitary and epidemiological conditions, exemplary for those times. 
Already in the mid-1840s Leszno citizens drew fresh water from dug or drilled wells nearby their homes. Additionally, a gravity-flow water-supply system operated in the town. The network of pipes distributing fresh water throughout the town was steadily expanded, along with the increase in the number of inhabitants ${ }^{51}$. In Leszno deaths from cholera accounted for only $0.26 \%$ of all deaths ${ }^{51}$. In the light of statistics, the epidemic threat was the lowest in villages of the Poznań Province. This was due to the low population density, including no access to contaminated water. In the studied Jastrzębsko Stare Parish, for instance, deaths from cholera accounted for about $0.1 \%$ of all deaths recorded there ${ }^{51}$.

Cholera epidemics in the Poznan Province in the second half of the $19^{\text {th }}$ century killed more women than men. Our results have confirmed that deaths of girls (teenagers and young women) and adult women during cholera epidemics outnumbered deaths of males (teenagers, young men and adult men). In the same age categories of non-epidemic periods, it was male deaths which outnumbered female ones, and this was a typical mortality pattern ${ }^{51}$. The increase in female deaths in times of cholera epidemic may have resulted from different social roles between females and males, which has already been discussed earlier in this work. Differences in cholera death rates may have had their source in societal norms, in the light of which women cared for the sick in homes, hospitals and shelters. Women performed waterrelated household activities and could have potentially contacted contaminated water by cooking, food preparation, cleaning and washing, etc., much more frequently than men. In the city of Poznań women drew water from shallow wells, which were often polluted with harmful sewage discharged directly to the Cybina River, the Warta River and the moats. They used water from the rivers directly for cooking, cleaning and washing. The annual sanitary reports on water cleanliness indicated the contamination with nitric acid, chlorine, ammonia, and hydrogen sulphide. There were also primitive street gutters with ineffective drainage full of contaminated water during the summer heat periods, into which women poured sewage ${ }^{50}$. 


\section{Methods}

\section{Historical background}

The work focuses on the territory of the Poznan Province (Provinz Posen), which upon the decision of the Prussian authorities dated on $1^{\text {st }}$ January 1816 was created from the lands of the Grand Duchy of Poznań. It consisted of two districts: the district of Poznań (Regierungsbezirk Posen) with its registered office in the city of Poznań and the district of Bydgoszcz (Regierungsbezirk Bromberg) with its registered office in the city of Bydgoszcz ${ }^{52}$. The Province was bordered by the Pomerania Province in the north, the Brandenburg Province in the west, the Silesia Province in the south, and the Kingdom of Poland in the east $^{52-53}$ (Fig. 1).

\section{Data}

The materials have been derived from death registers of parishes located in the Poznan Province for the years 1850-1905.The books were kept in Polish, Latin and German. The study has used data for six selected parishes located in the city of Poznań: St. Mary Magdalene, St. Margaret and St. Martin, St. Roch, St. Peter and the Holy Cross, the Holy Cross parish from a smaller administrative town centre Leszno, and from three rural parishes: Jastrzębsko Stare, Nekielka and Trzebosz. Currently parish death registers are deposited in the State Archive in Poznań.

According to Prussian administration, urban communities with fewer than 20,000 inhabitants belonged to the category of towns (Stadtgemeinden). Urban centres exceeding 20,000 population at the end of the $19^{\text {th }} \mathrm{c}$., or over 50,000 population at the beginning of the $20^{\text {th }}$ c., belonged to the category of "city" (Städte mit 20000 Einwohner und drüber $)^{51}$. In the second half of the $19^{\text {th }}$ and early $20^{\text {th }}$ centuries, the rural population of the Poznan Province outnumbered its city inhabitants. In the 1850s villages of the region (rural areas; Landgemeiden) were inhabited by more than $70 \%$ of the population, and towns by about $30 \%$. 
In 1910 the rates of rural to urban inhabitants changed only slightly and were $66 \%$ and $34 \%$, respectively ${ }^{54}$. The capital city of the Province was the city of Poznań. In 1850s Poznań had 45,000 inhabitants ${ }^{55}$. Forty years later 130,000 people lived in Poznań ${ }^{56}$. A small town in this work was represented by Leszno, which in the 1850s and in the 1890s had 10,000 and 13,000 inhabitants, respectively ${ }^{55-57}$.

Data derived from parish death registers include the following individual information: the individual's date of death (day-month-year), place of residence, age at death and cause of death. In total, 34,655 individual records with recognized causes of death were examined for the purpose of this study, i.e. 18,243 males and 16,325 females. Within the variable "place of residence" 3 categories were distinguished: 0) Poznań, i.e., the capital city of the Poznań Province; 1) towns, and 2) rural areas.

In all cases of deaths due to cholera they were recorded as cholera. Symptoms of the disease are easy to recognize. Hence, in the period under study deaths due to cholera were rather correctly diagnosed and distinguished from deaths by other causes, for example diarrhoeas, vomiting or food poisoning, giving similar symptoms to cholera were recorded as diarrhoea, abdominal pain and vomiting ${ }^{58}$.

\section{The daily and weekly cholera incidences}

The numbers of all death and deaths due to cholera recorded per day and per week are shown in Figs. 2a-2d. Generally, the numbers of deaths in non-epidemic periods varied from 1 to just a few per day. During cholera epidemics, the numbers of deaths increased to over 20

per day and to 120 per week. The daily and weekly incidences of cholera were counted for the epidemics in 1852, 1855, 1866 and 1873 from their onsets (the first death recorded) to their ends (the last death recorded), and the relations of male-to-female deaths numbers by epidemiological weeks have been computed. 


\section{The theoretical and empirical distributions of deaths}

The differences between the theoretical and empirical distributions in the numbers of male and female deaths have been examined. The following situations have been proposed for the analysis:

a) assumed numbers of male $(\mathrm{N}=17,284)$ and female $(\mathrm{N}=17,284)$ deaths against empirical numbers of male $(\mathrm{N}=18,243$ males $)$ and female $(\mathrm{N}=16,325)$ deaths;

b) assumed numbers of male $(\mathrm{N}=451)$ and female $(\mathrm{N}=451)$ deaths from cholera against empirical numbers of male $(\mathrm{N}=436)$ and female $(\mathrm{N}=466)$ deaths due to cholera;

c) numbers of male $(\mathrm{N}=17,807)$ and female $(\mathrm{N}=15,859)$ deaths not related to cholera occurrences against numbers of male $(\mathrm{N}=436)$ and female $(\mathrm{N}=466)$ deaths during cholera occurrences.

From the numbers of male and female deaths the sex ratio at death (sex-specific mortality rate) has been calculated, separately for the material as a whole (sex ratio at death, SRD) and for deaths from cholera (sex ratio at death due to cholera, SRDCh). The sex ratio at death is defined as the rate of male deaths to female deaths. Differences in theoretical and empirical distributions of SRD and SRDCh have been investigated. The following situations have been proposed:

a) $\mathrm{SRD}=1$ (i.e. equal rate of male and female deaths);

b) SDR > 1 (i.e. more men died than women);

c) $\mathrm{SRDCh}=1$ (i.e. equal rate of male and female deaths from cholera);

d) $\mathrm{SRDCh}>1$ (i.e. more men than women died from cholera).

Differences in SRD and SRDCh by size of the place of residence have also been examined. In all cases Pearson's Chi-squared test with Yates' continuity correction (function chisq.test) in the software $\mathrm{R}^{59}$ for testing statistical differences has been applied. 


\section{Summary}

Four cholera epidemics that took place in the Poznan Province in the second half of the $19^{\text {th }}$ century caused more deaths among women than men. The reasons for such epidemic outcomes are sought, as in the case of countries where cholera epidemics occur currently, in differences in the division of social roles between women and men. Nevertheless, a more thorough research is needed to investigate gender-specific deaths rates due to cholera, taking into account the division of society according to indicators of socio-economic status, i.e., occupation, religious denomination, etc.

\section{References}

1. Morrow, E. H. The evolution of sex differences in disease. Biol. Sex Differ. 6, 1-7 (2015).

2. Vázquez-Martínez, E. R., García-Gómez, E., Camacho-Arroyo, I. \& González-Pedrajoet, B. Sexual dimorphism in bacterial infections. Biol. Sex Differ. 9, 1-20 (2018).

3. Preston, S. H. Mortality patterns in national populations: With special reference to recorded causes of death (Academic Press, 1976).

4. Battles, H.T. The biologically vulnerable boy: Framing sex differences in childhood infectious disease mortality. Boyhood Stud. 9, 56-72 (2016).

5. Garenne, M., \& Lafon, M. Sexist diseases. Perspect. Biol. Med. 41, 176-190 (1998).

6. Garenne, M. Sex Differences in measles Mortality: A World Review. Int. J. Epidemiol. 23, 632-642 (1994).

7. Singh, D., Wander, G. S. \& Singh, R.J. Gender equality in India for children with congenital heart disease: looking for answers. BMJ Journals Heart 23 (2011).

8. Singh, J. \& Datta, K. K. Measles vaccine efficacy in India: a review. J. Comm. Dis. 29, 47-56 (1999).

9. Voskuhl, R. Sex differences in autoimmune diseases. Biol. Sex. Differ. 2, 1-21 (2011). 
10. Garenne, M. Demographic Evidence of Sex Differences in Vulnerability to Infectious Diseases. J. Infec. Dis. 211, 331-332 (2015).

11. Ell. S. Three days in October of 1630: Detailed examination of mortality during an early modern plague epidemic in Venice. Rev. Inf. Dis. 11,128-139 (1989).

12. Frandsen, K-E. The last plague in the Baltic region, 1709-1713 (Museum Tusculanum Press, 2010).

13. Pérez Moreda, V. La peste de 1647-57 en el Mediterraneo occidental. Boletín de la Asociación de Demografía Histórica 5, 14-23 (1987).

14. Signoli, M. Séguy, I., Biraben, J-N. \& Dutour, O. Paleodemography and historical demography in the context of an epidemic: Plague in Provence in the eighteenth century. Population 57, 829-854 (2002).

15. Curtis, D. R. \& Roosen, J. The sex-selective impact of the Black Death and recurring plagues in the Southern Netherlands, 1349-1450. Am. J. Phys. Anthropol. 164, 246-259 (2017).

16. Hollingsworth, M. \& Hollingsworth, T. Plague mortality rates by age and sex in the parish of St. Botolph's without Bishopgate, London, 1603. Pop. Stud. 25, 131-146 (1971).

17. Alfani, G. \& Murphy, T. Plague and lethal epidemics in the preindustrial world. J. Econ. Hist. 77, 314-343 (2017).

18. Johansson, S.R. Welfare, mortality, and gender. Continuity and change in explanations for male/female mortality differences over three centuries. Con. Change 6, 135-177 (1991).

19. Bird, Ch. E. \& Rieker, P. P. Gender and Health. The Effects of Constrained Choices and Social Policies (Cambridge University Press, 2008).

20. Fish, E.N. The X-files in immunity: sex-based differences predispose immune responses. Nature 8, 737-744 (2008). 
21. Pennell, L.M., Galligan, C. L., Fish, E.N. Sex affects immunity. J. Autoimmun. 38, J282J291 (2012).

22. Zarulli, V., Barthold Jones, J.A., Oksuzyan, A., Lindahl-Jacobsen, R., Christensen,K. \& Vaupel, J. W. Women live longer than men even during severe famines and epidemics. PNAS 8, E832-E840 (2018).

23. Muenchhoff, M. \& Goulder, P. J. Sex differences in pediatric infectious diseases. J. Infect. Dis. 209, S120-S126 (2014).

24. Haring R. et al. Low serum testosterone levels are associated with increased risk of mortality in a population-based cohort of men aged 20-79. Eur. Heart. 31, 1494-1501 (2010).

25. Muehlenbein, M. P.\& Bribiescas, R. G. Testosterone-Mediated Immune Functions and Male Life Histories. Am. J. Hum. Biol. 17, 527-558 (2005).

26. Wizemann TM, Pardue M-L. Exploring the Biological Contributions to Human Health. Does Sex Matter? (National Academy of Press, 2001).

27. Avdic, D., Hägglund, P., Lindahl, B. \& Johansson P. Sex differences in sickness absence and the morbidity-mortality paradox: a longitudinal study using Swedish administrative registers. $B M J$ 9, e024098 (2019).

28. Aaby, P. Are men weaker or do their sisters talk too much? Sex differences in childhood mortality and the construction of 'biological' differences. (eds. Basu, A.M. \& Aaby, P. editors) The Methods and Uses of Anthropological Demography (Clarendon Press, 1998).

29. Mooney, G. Shifting sex differentials in mortality during urban epidemiological transition: the case of Victorian London. Internat. J. Popul. Geog. 8, 17-47 (2002).

30. Sevilimedu, V. et al. Gender-based differences in water, sanitation and hygiene-related diarrheal disease and helminthic infections: a systematic review and meta-analysis. Trans. R. Soc. Trop. Med. Hyg. 1-12 (2017). 
31. Bekolo, C.E., van Loenhout, J.A.F., Rodriguez-Llanes, J.M., Rumunu, J., Ramadan, O.P. \& Guha-Sapide, D. A retrospective analysis of oral cholera vaccine use, disease severity and deaths during an outbreak in South Sudan. Bull. World Health Organ. 94, 667-674 (2016).

32. de Magny, G. C. et al. Role of Zooplankton Diversity in Vibrio cholerae Population Dynamics and in the Incidence of Cholera in the Bangladesh Sundarbans. Appl. Environ. Microbiol. 17, 6125-6132 (2011)

33. Mari, L., Bertuzzo, E., Righetto, L., Casagrandi, R., Gatto, M., Rodriguez-Iturbe. I. \& Rinaldo, A. Modelling cholera epidemics: the role of waterways, human mobility and sanitation. J. R. Soc. Interface 9, 376-388 (2012).

34. Cvjetanovic, P. \& Barua, D. The Seventh Pandemic of Cholera. Nature 239, 137-138 (1972).

35. Harris, J. B., LaRocque, R. C., Qadri, F., Ryan, E. T. \& Calderwood, S. B. Cholera. Lancet 379, 2466-2476 (2012).

36. Hu, D. et al. Origins of the current seventh cholera pandemic. Proc. Nat. Acad. Sci. USA 113, E7730-E7739 (2016).

37. Ali, M. et al. The global burden of cholera. Bull. World Health Organ. 90, 209-218 (2012).

38. World Health Organization. Addressing Sex and Gender in Epidemic-Prone Infectious Diseases (WHO, 2007).

39. Agtini, M. D. et al. The burden of diarrhoea, shigellosis, and cholera in North Jakarta, Indonesia: findings from 24 months surveillance. BMC Infectious Diseases 89, 1-11 (2005). 
40. Tutu, R.A., Gupta, S., Elavarthi, S., Busingye, J. D. \& Boateng, JK. Exploring the development of a household cholera-focused health literacy scale in James Town, Accra. J. Infect. Pub. Health 12, 62-69 (2019).

41. Glass, R. I. et al. Endemic cholera in rural Bangladesh, 1966-1980. Am. J. Epidemiol. 116, 959-970 (1982).

42. Cummings, M. J. et al. A cholera outbreak among semi-nomadic pastoralists in northeastern Uganda: epidemiology and interventions. Epidemiol. Infect. 140, 1376-1385 (2012).

43. Sigudu, T.T., Tint, K.S. \& Archer, B. Epidemiological description of cholera outbreak in Mpumalanga Province, South Africa. South Afr. J. Infect. Dis. 30,125-128 (2015).

44. Rancourt, N. Gender and Vulnerability to cholera in Sierra Leone. Gender analysis of the 2012 cholera outbreak and an assessment of Oxfam's response (Oxfam Research Reports, 2013).

45. Bwire, G. et al. Epidemiology of cholera outbreaks and socio- economic characteristics of the communities in the fishing villages of Uganda. PLoS Negl. Trop. Dis. 11, e0005407 (2017)

46. Watanabe, K., Kato, J., Zhu, J., Oda, H., Ishiwata-Endo, H., \& Moss, J. Enhanced sensitivity to cholera toxin in female ADP-ribosylarginine hydrolase (ARH1)-deficient mice. PLoSONE 13, e0207693 (2018).

47. Kędelski, M. Stosunki ludnościowe w latach 1815-1918 (eds. Topolski, J. \& Trzeciakowski, L.) Dzieje Poznania 1793-1918, t. 2. ( Wydawnictwo Naukowe PWN, 1994).

48. Liczbińska, G. Infant and Child Mortality among Catholics and Lutherans in Nineteenth century Poznań200. J. Bio. Sc. 41, 661-683 (2009). 
49. Trzeciakowska, M. \& Trzeciakowski, L. W dziewiętnastowiecznym Poznaniu (Wydawnictwo Poznańskie, 1987).

50. Kaniecki, A. Poznań. Dzieje miasta woda pisane (Wydawnictwo Poznańskiego Towarzystwa Przyjaciół Nauk, 2004).

51. Liczbińska, G. Lutherans in the Poznan province. Biological dynamics of the Lutheran population from the 19th century and early 20th centuries (Verlag Dr. Kovač, 2015).

52. Kozłowski, J. Wielkopolska pod zaborem pruskim w latach 1815-1918 (Wydawnictwo Poznańskie, 2004).

53. Sulimierski, F., Chlebowski, B. \& Walewski, W. Słownik Geograficzny Królestwa Polskiego i innych krajów słowiańskich (Wiek-Nowy Świat, 1880-1902).

54. Borowski, S. Rozwój demograficzny i problem maltuzjański na ziemiach polskich pod panowaniem niemieckim w latach 1807-1914. Przeszłość Demograficzna Polski 3, 125$142(1969)$.

55. Preussische Statistik. Die Bewegung der Bevölkerung. Die Geburten, Ehe-schliessungen und Sterbefälle. Herausgegeben in zwanglosen Heften vom Königliche Preussischen Statistischen Bureau in Berlin (Königliche Preussischen Statistischen Bureau in Berlin, 1866).

56. Preussische Statistik. Die Bewegung der Bevölkerung. Die Geburten, Ehe-schliessungen und Sterbefälle. Herausgegeben in zwanglosen Heften vom Königliche Preussischen Statistischen Bureau in Berlin (Königliche Preussischen Statistischen Bureau in Berlin, 1896).

57. Urbaniak, M. Modernizacja infrastruktury miejskiej Leszna w latach 1832-1914 (Wydawnictwo Poznańskie, 2009). 
58. Wróbel, M. Cholera na Białostocczyźnie w latach dziewięćdziesiątych XIX w. i krzyże ją upamiętniające (ed. Zemło, M.) Małe Miasta Codzienność (Wydawnictwo Uniwersytetu w Białymstoku, 2019).

59. R Core Team. R: A Language and Environment for Statistical Computing (R Foundation for Statistical Computing, 2019) https://www.R-project.org/.

\section{Authors' contributions}

GL contributed to study conception and design, establishing the database, analysis and interpretation of data, writing the main manuscript, preparing figure 1, drafting and critical revision of manuscript.

MK contributed to data computing, analysis and interpretation of data, preparing figures 2-6, drafting and critical revision of manuscript.

All authors read and approved the final manuscript.

\section{Competing interests}

The author(s) declare no competing interests.

\section{Data availability}

Data sharing not applicable to this article as no data-sets were generated or analyzed during the current study.

\section{Ethics approval and consent to participate}

This study has been based on archival data and therefore does not require approval by any ethics committee.

\section{Figures legend}

Figure 1. The territory of Poznań Province highlighted in the map of contemporary Poland Figure 2. Distribution of all deaths in the studied period by days

a. Daily deaths - all cases 
b. Weekly deaths - all cases

c. Male-to-female weekly deaths - all cases

d. Daily and weekly deaths due to cholera

Figure 3. Distribution of deaths by epidemiological days and weeks
a. Cholera epidemic, 1852
b. Cholera epidemic, 1855
c. Cholera epidemic, 1866
d. Cholera epidemic, 1873

Figure 4.Male-to-female death ratio by epidemiological weeks
a. Cholera epidemic, 1852
b. Cholera epidemic, 1855
c. Cholera epidemic, 1866
d. Cholera epidemic, 1873

Figure 5. Distributions of the fatal cases by age outside cholera epidemics and during cholera epidemics

Figure 6.Distribution of the density of fatal cases by age outside cholera epidemics and during cholera epidemics. 
Figures

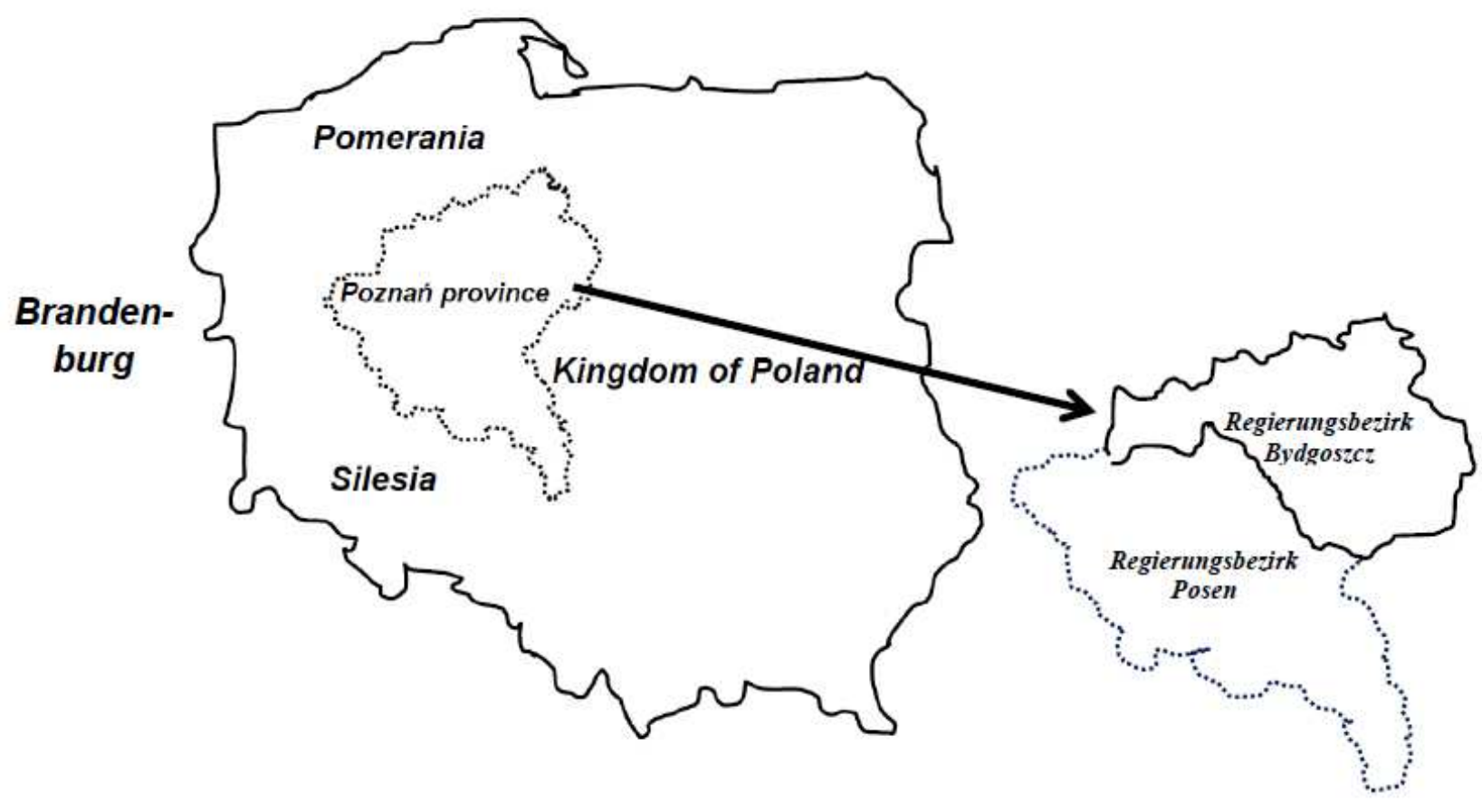

Figure 1

The territory of Poznań Province highlighted in the map of contemporary Poland 
a

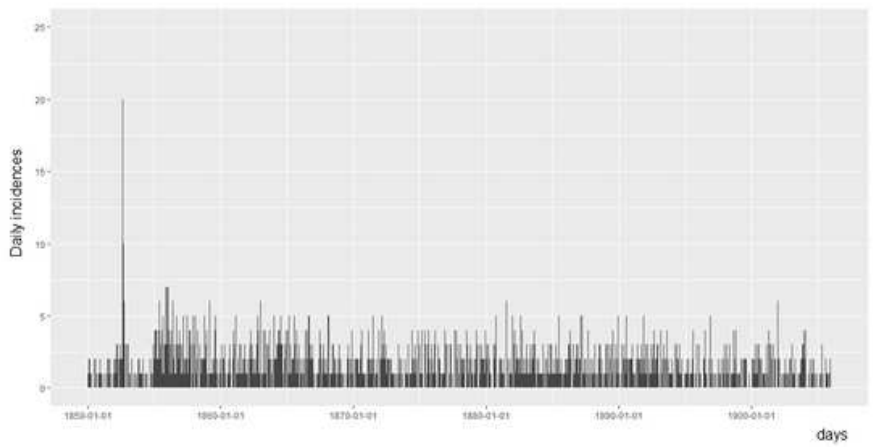

C

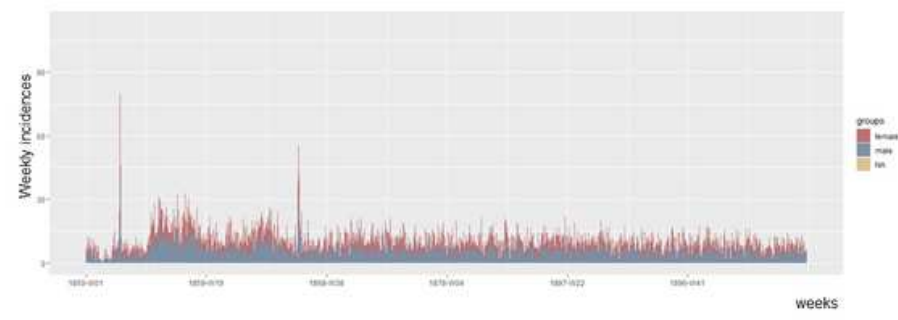

b

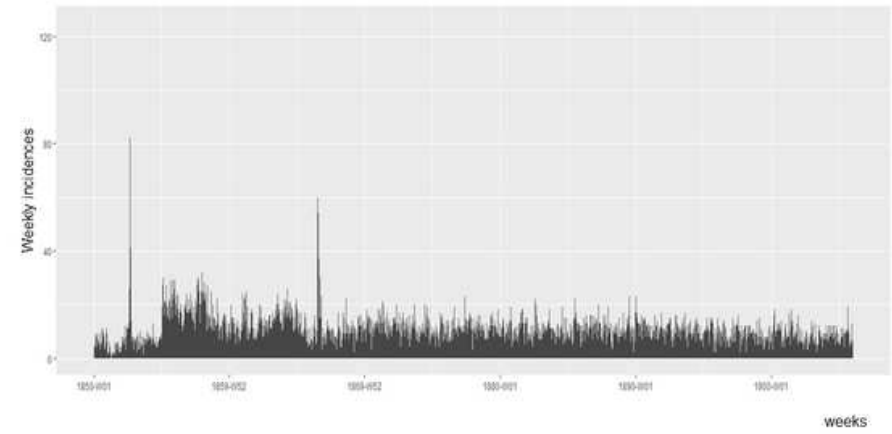

d

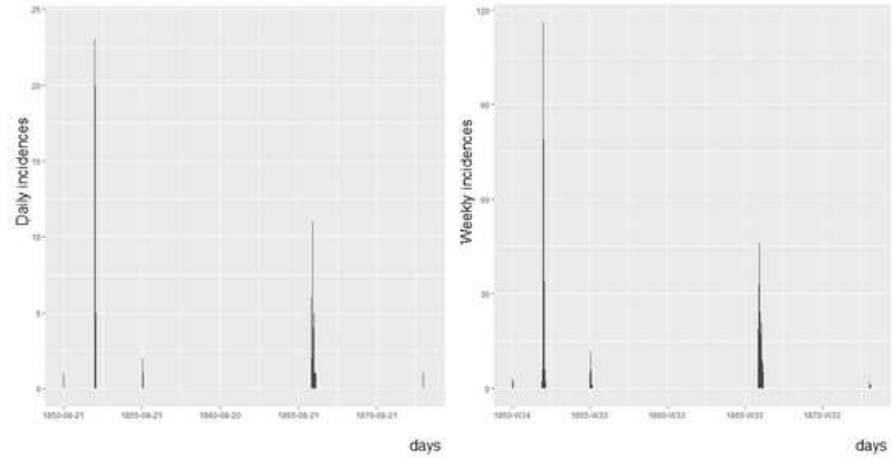

Figure 2

Distribution of all deaths in the studied period by days a. Daily deaths - all cases b. Weekly deaths - all cases c. Male-to-female weekly deaths - all cases d. Daily and weekly deaths due to cholera 

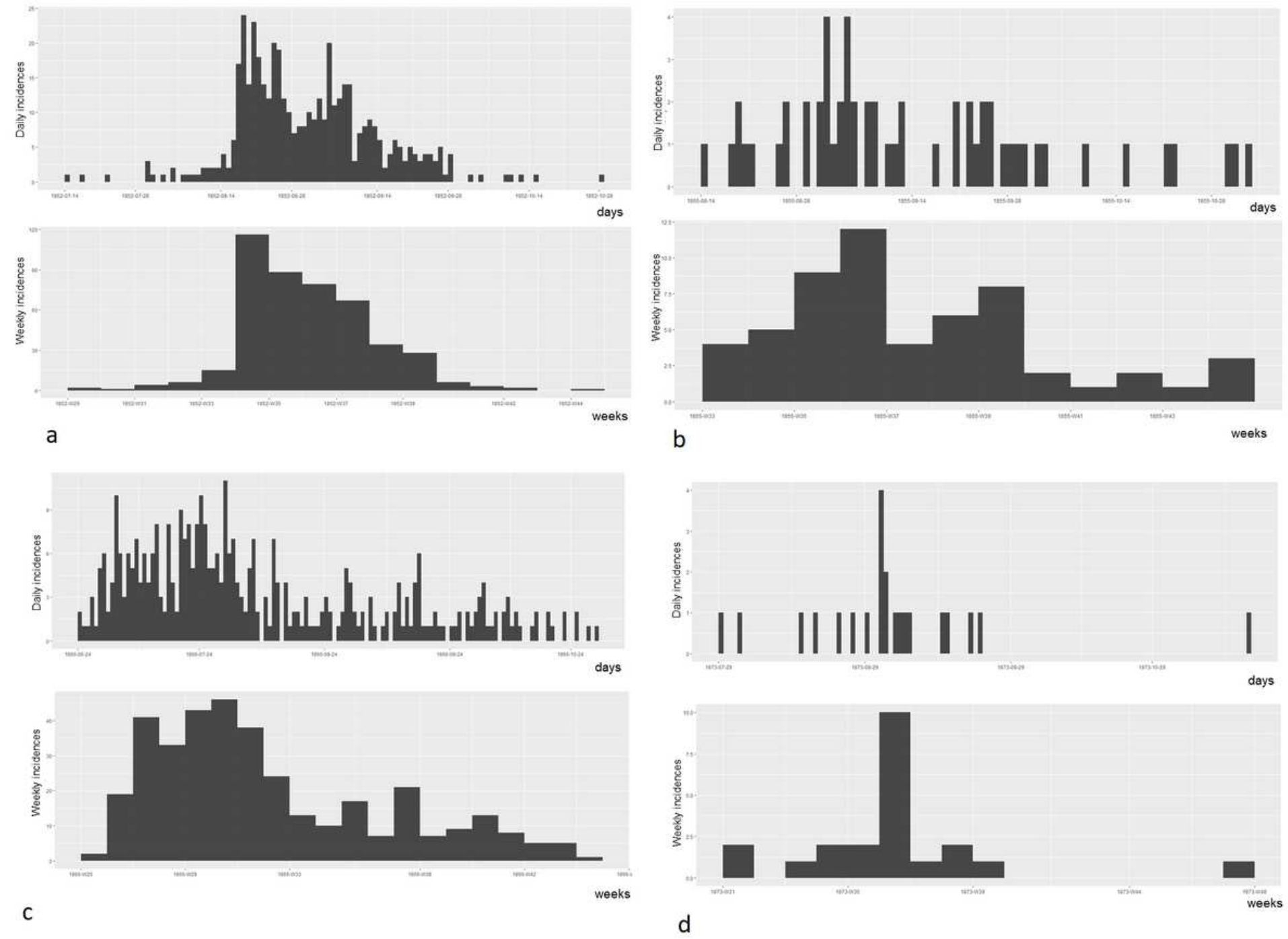

Figure 3

Distribution of deaths by epidemiological days and weeks a. Cholera epidemic, 1852 b. Cholera epidemic, 1855 c. Cholera epidemic, 1866 d. Cholera epidemic, 1873 
a

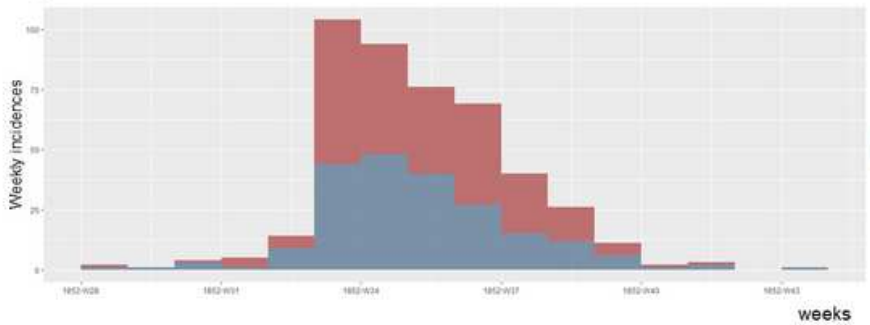

C

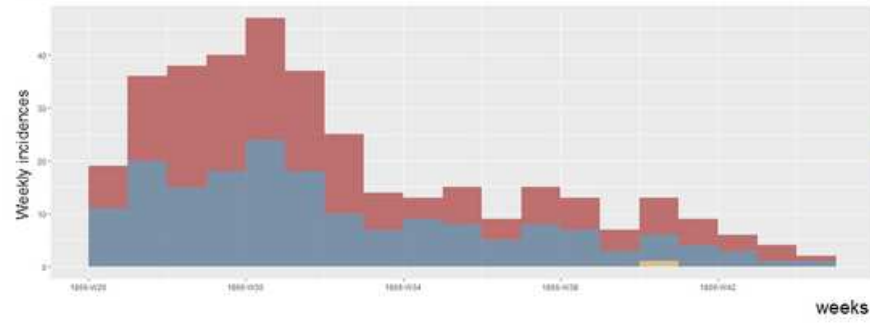

b

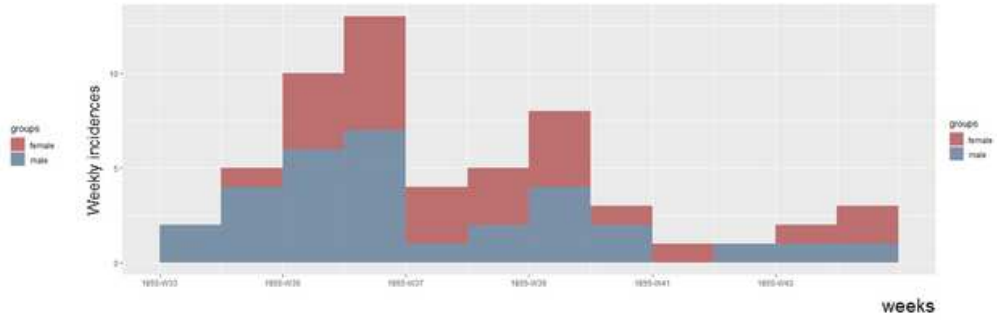

d

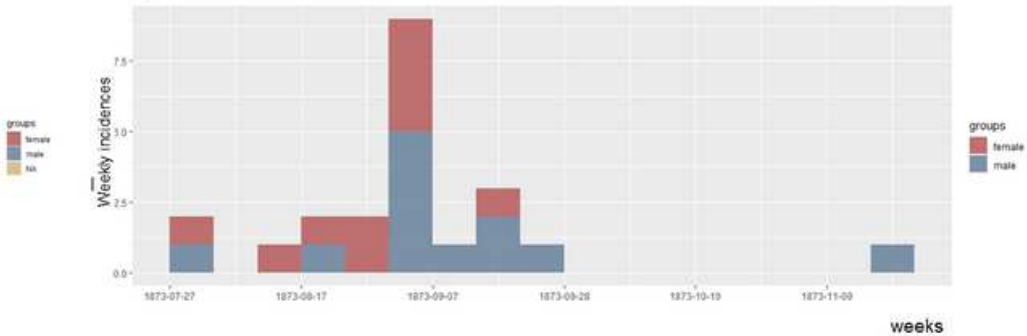

Figure 4

Male-to-female death ratio by epidemiological weeks a. Cholera epidemic, 1852 b. Cholera epidemic, 1855 c. Cholera epidemic, 1866 d. Cholera epidemic, 1873
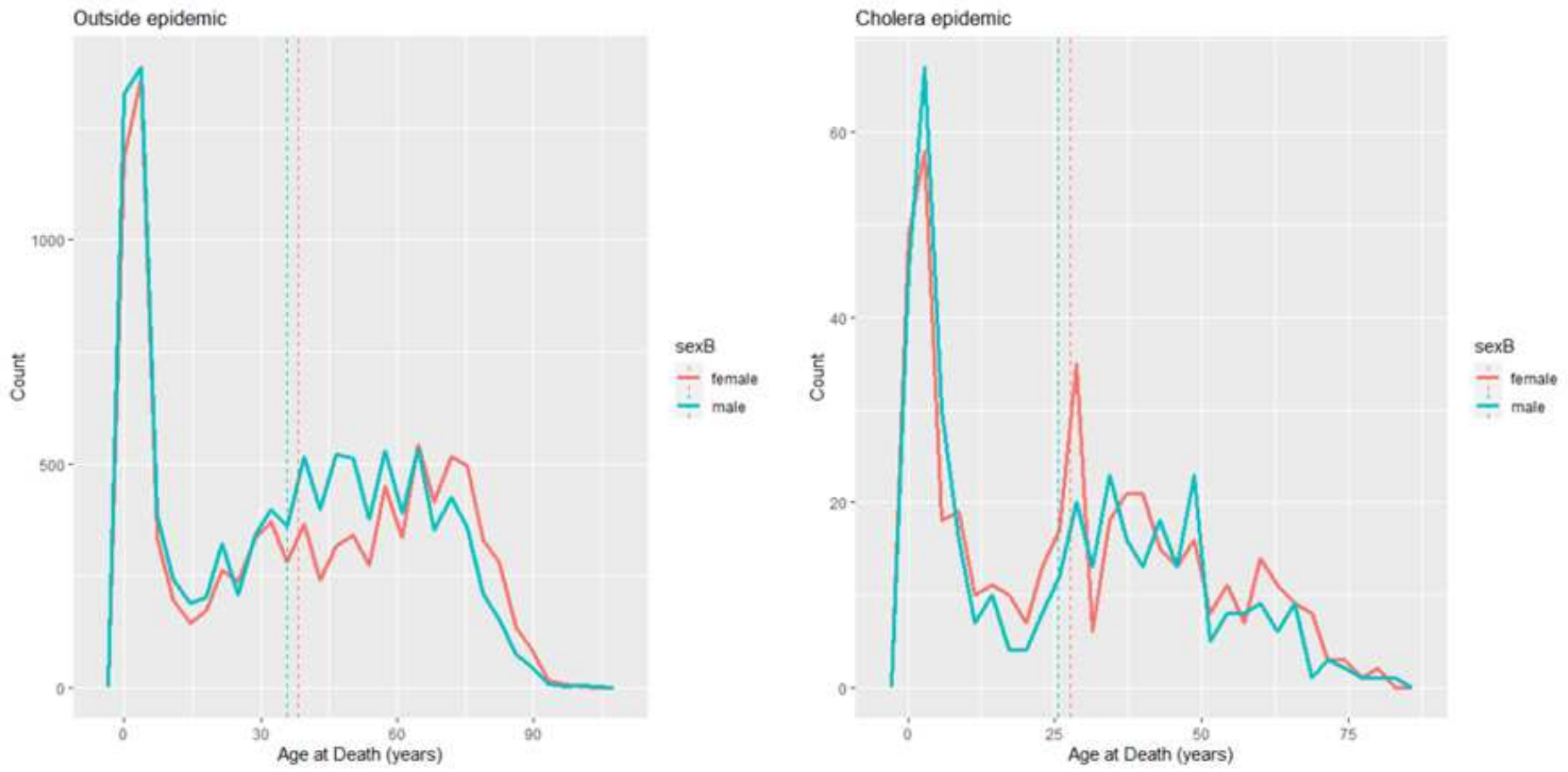

Figure 5

Distributions of the fatal cases by age outside cholera epidemics and during cholera epidemics 

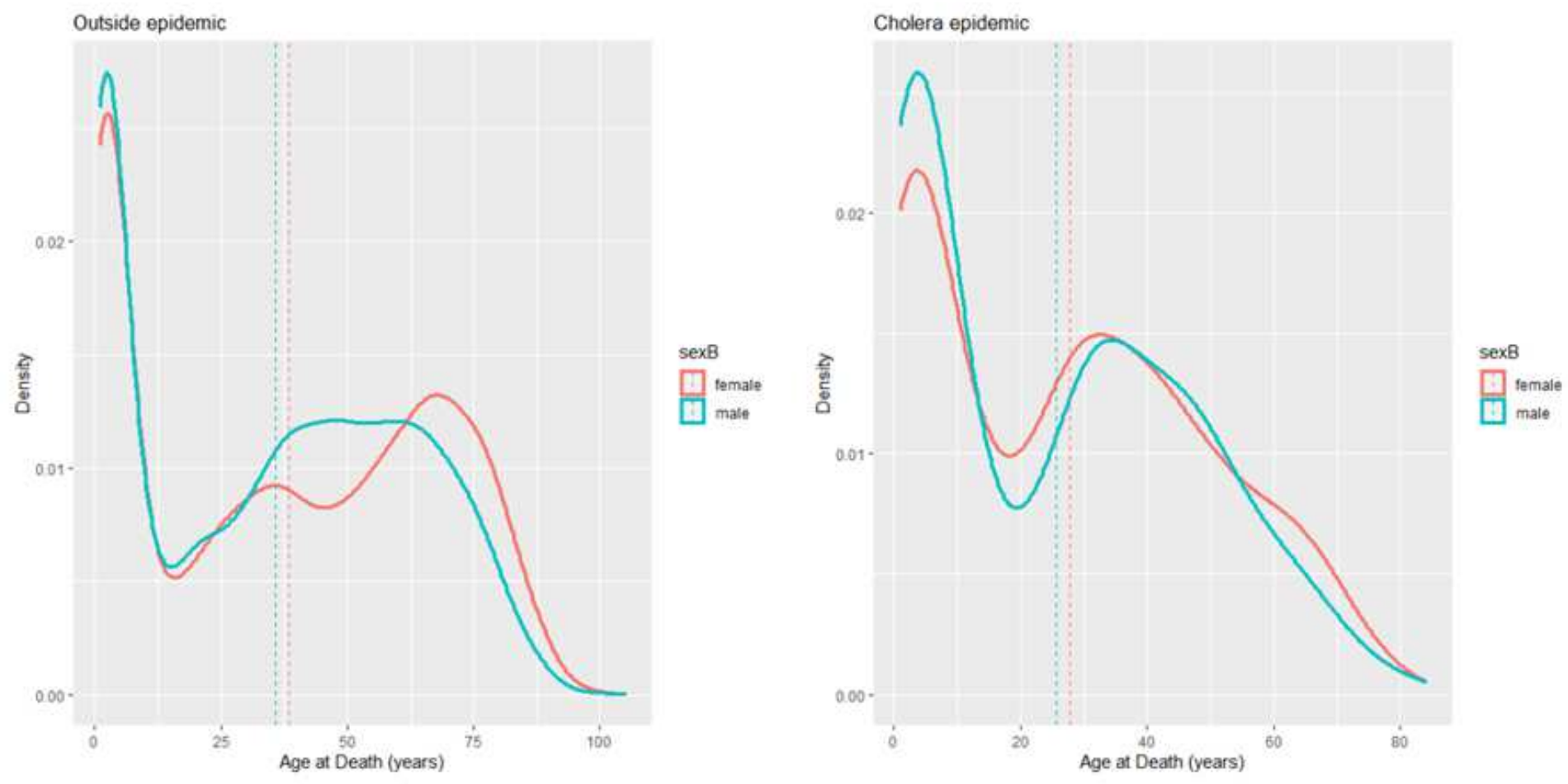

Figure 6

Distribution of the density of fatal cases by age outside cholera epidemics and during cholera epidemics. 